\title{
ДІАЛЕКТИЗМИ В СУЧАСНОМУ ПОЕТИЧНОМУ МОВЛЕННІ
}

Пена Л. І. Діалектизми в сучасному поетичному мовленні.

У статті проаналізовані різнорівневі діалектизми в поетичних творах Івана Малковича. Особлива увага звертається на лексичні діалектизми: визначено їх розряди за частиномовною належністю, наведено семантичні групи, з'ясовано роль у поетичних текстах.

Ключові слова: діалектизм, гуцулізм, поезія, Іван Малкович.

Пена Л. И. Диалектизмы в современной поэтической речи.

В статье проанализированы разноуровневые диалектизмы в поэтических произведениях Ивана Малковыча. Особенное внимание уделяется лексическим диалектизмам: выделены их разряды по частеречной принадлежности, наведены семантические группы, определена роль в поэтических текстах.

Ключевые слова: диалектизм, гуцулизм, поэзия, Иван Малковыч.

Pena L. I. Dialectisms in modern poetical speech.

The autor examines in the article the different dialectisms' levels in the poetic works of Ivan Malkovych. Particular attention is drawn to the lexical dialectisms: it was determined their classification according to the parts of language, the semantic groups and the role in the poetic texts.

Key words: dialectism, hutsulism, poetry, Ivan Malkovych.

Мова творів письменників постійно перебуває в центрі уваги лінгвістів, адже художня література є не звичайним споживачем мовних ресурсів. У ній слова завдяки несподіваній сполучуваності 3 іншими словами можуть набувати найрізноманітнішої семантики чи їі відтінків, використовуватися в переносних значеннях тощо. Слово під пером майстра оживає, починає «вигравати» всіма своїми барвами, захоплюючи читача, формуючи в нього естетичний смак. Також художнє мислення вимагає від митця не простого вибору вже існуючих у мові певних форм та лексичних засобів, які були б найбільш відповідними до змісту, стилю та ситуації мовлення; спонукає до постійного пошуку нових, іноді зовсім несподіваних та неочікуваних зображальних мовних ресурсів. До когорти таких, на нашу думку, належить сучасний поет Іван Малкович. Ці та інші індивідуально-авторські неолексеми різних лексико-граматичних розрядів органічно вплітаються в поетичну текстову канву, надають свіжості віршам, а їх автора характеризують як творчу особистість, який відчуває красу рідного слова і володіє даром зачаровувати таїною мови читачів. А саме талановиті майстри покликані формувати відчуття рідного слова, замилування ним, бажання влучно й 
гармонійно висловлюватися. Поетичні полотна І. Малковича відповідають цим вимогам, приносячи естетичну насолоду читачеві, тому його творчість високо цінується сучасниками, про що свідчать численні позитивні відгуки, уривок одного з яких наведемо тут: «Без нього важко уявити українське культурне життя останніх десятиріч. Надзвичайно тонкий, поліфонічний поет, чий прихід у літературу був привітаний Ліною Костенко, а поява кожної збірки викликала неабиякий резонанс, чиї вірші сприймаються багатьма як символ цілого покоління, «творець порцелянових міст» і різдвяних феєрій. А за сумісництвом - ще й Дон-Кіхот вітчизняного дитячого книговидання, успішний видавець, чільник чи не найрейтинговішого українського видавництва. Постать, котра щасливо поєднала в собі непоєднувані, здавалося б, речі. Людинаоксюморон. Все це - Іван Малкович» [7, с. 302].

Ще однією, на наш погляд, досить яскравою, ознакою мовного портрета I. Малковича є присутність у його творах рис рідної говірки. Пропонована стаття присвячена розгляду діалектних особливостей поезій I. Малковича, які проявляються на різних мовних рівнях. Актуальність теми зумовлена тим, що «студії над використанням місцевих діалектів в українській літературі, як, зрештою, й у інших літературах, $є$ досить важливим завданням сучасної лінгвістики, оскільки дають змогу з'ясувати, які з діалектних рис, у якому обсязі, яким чином і 3 якою метою вжиті в мові художньої літератури» [1, с. 290]. А, як зазначає далі В. Грещук, «грунтовний аналіз використання різнорівневих говіркових мовних одиниць в історії розвитку української белетристики уможливлює з'ясування проблеми взаємодії літературної мови і їі діалектів» [1, с. 290].

Фонетичні особливості говірки у віршах I. Малковича представлені досить обмежено, оскільки поетичне мовлення $є$ переважно монологічним; однак трапляються поодинокі випадки використання голосних $e$, $i$ замість а після м'яких приголосних (пістолєтко; поволочивсі - у мовленні персонажа), а також властиве для гуцульського говору скорочення звукового складу слів (мо’ замість може, не тра' - замість не треба). Серед морфологічних ознак рідного для поета говору відзначимо вживання закінчення $-u$ в родовому (людности) і давальному (Іванови) відмінках іменників однини, деякі відмінні від сучасних літературних фонетичні варіанти відмінкових форм займенників (на ню, на него, а також сей, ся, се), редупліковані форми займенників (тота), використання закінчення -е замість -ить у дієсловах третьої особи однини теперішнього і майбутнього часів другої дієвідміни (полюбе, баче), написання ся окремо від дієслівних 
форм та у препозиції щодо них (мене ся не боїть), форми умовного способу, утворені за допомогою частки бим і форми минулого часу (розтяв бим тебе, любко). Словотвірні особливості репрезентовані частим вживанням дериваційних формантів -оньк- (дрібонький, легонький) та -енн- (теменний, чоренний).

Про належність автора до гуцулів як окремої етнічної групи, його тісний зв'язок із ними промовисто свідчить те, що час від часу в його поетичних замальовках зринають номінації цих колоритних жителів Карпатських гір та різночастиномовні похідні від них. Напр.: Я заграю в зозульку із глини, / спогадаю гуцульську журбу [5, с. 35]; Від’̈жджаю: в вікні мама з татом, / як гуцульські ікони на склі [5, с. 104]; ...кожен гуцул / після відходу / ще мусить здолати / останню свою / Чорногору [5, с. 121]; Гори плечима загати, / щуоб не зсувалися на неї по ночах, / ... аби в теменнім лісі їй, самій, / не привиджалися біленькі гуцулята [4, с. 198]; о низеньке старе піддашшя / з шурхотливими мара касами осиних гнізд / у яких здавна зумкотіла / маленька гуцульська джаза-мантеляза [5, с. 70] та ін.

Широко репрезентована в поетичних полотнах I. Малковича неповторна гуцульська лексика, маніфестована словами різних лексико-граматичних розрядів. Найбільшу групу становлять іменникові номінації. 3 гуцульських діалектних назв осіб використані лексеми, що кваліфікують людей за віковими характеристиками (дідо «дід»), майновим статусом (газда «господар»), належністю до війська (жовняр «військовик, солдат»), тимчасовим станом (князь «молодий (на весіллі)», княгиня «молода (на весіллі)», любчик «коханий»): На хлібі три пташки-зозульки, а тісто - глевке - $і$ тому / западається в центрі княгиня із князем на бричиі [5, с. 79]; Відпродай, газдо, мені хату, / вино, і віск, і решту свіч, / аби я мав де панувати / $i$ банувати ніч у ніч [4, с. 197]; а ще бачу як зараз: дідо сидить в глибині при відчинених дверях / картоплю на дві половинки розрізує для садіння / $і$ співає про сербана який по зарінку ходить [4, с. 212] та ін.

Розмаїття рослинного світу карпатського краю, серед якого пропливає життя гуцулів, представлене такими номінаціями: без «бузок», ива «бот. верба», кобили «вид квасолі, велика квасоля», лен «льон», ружа «квітка», трепета «осика», юрінки «бот. калюжниця болотна», яфери «чорниці». Напр.: Рутка в зеленім, хата в покрівлі, / в синім - ожина, / ива-маржина стоїть в надвечірнім, / ива-маржина [5, с. 71]; ангелик в яферах дрімав / $i$ все гадав, щчо нам тут добре [4, с. 215]; в руиі - маю ружу, / язик - за оружжа, / а в сериі / якась / коляда [5, с. 83]; у цчі протрухлі ворота / вплітали колись жовтенькі 
юрінки / аби Юра на білім коні / подвір'я не витоптував [5, с. 80]. Тваринний світ репрезентований такими номінаціями: маржсиа «худоба», матиия «єдина на всю сім’ю бджола, що відкладає яйця, матка», мицько «кіт», мурашок «мурашка», гад, гадина «гадюка», жонова «дятел». Напр.: вівиі мої вівці / ніжна моя маржино / не поколіть собі губи / у чорну ожину [5, с. 110]; може то бджолина матиця в біленькім вулику / щзось нам гарне пророчить [5, с. 114].

Представлена у творах I. Малковича лексика на позначення специфічних гуцульських музичних інструментів: флояра «довга сопілка без денця», циимбали, родова та видова назви танців данчик «танець», дрібушка «назва танцю». Напр.: вівці мої вівці / я ваш панчик / зірвіть собі по конюшинці - / підем у данчик [5, с. 110]. Семантично спорідненою з названою групою є номінація бай «забава, вечірка, бенкет».

Засвідчені і слова, що позначають географічні об’єкти: зарінок «1) місце біля річки, устелене галькою; 2) лука, пасовище біля річки», звір «1) міжгір'я, ущелина, вузька долина між горами (переважно 3 джерелом); 2) гірське джерело, потік; 3) непрохідне місце, провалля», кашиця «дамба 3 колод; плетене укріплення берега і каміння на річці», полонина «високогірне пасовище». Напр.: $i$, ніби Черемош в кашиці, / далекий жаль мій в стіни б’ $\epsilon$ [5, с. 124]; Плекало волею цүі звори, / а звіра - кров'ю - щзоб напився, / щзоб гордими лишались гори / й хоч хтось в цім світі не скорився [5, с. 34]. Низкою гуцульських діалектизмів репрезентовані назви будівель різного призначення та їх частин: стая «постійне або тимчасове житло на полонині, де живуть пастухи влітку і переробляють молочні продукти», листівник «повітка для листя», пивниия «погріб, льох», стрих «горище (над хатою)», копиия «невеличкий стіжок сіна (20-25 кг)», комінок «димар», футрина «накладна планка, що обрамляє вікна або двері». Напр.: В темній стаї проти ночі / я вогонь косичив вище, ти дивилась в мої очі, / доки їх не виїв дим ще [4, с. 196] та ін. 3 господарською діяльністю горян пов'язані найменування поліг «скошена трава», зніща, зніщзатко «маленьке (аномальне) куряче яйце», чвертка «четверта частина чогось»: Покосили мої полонини / так, щчо й досі поліг не згребу [4, с. 54]; дідо чверточку колоди / відколов - і аж заплакав: / була вона, як століття, / а без чверті-наче дідо [5, с. 129].

Кількісно великою групою лексичних діалектизмівсубстантивів є назви речей домашнього вжитку: лавка «великий ослін, що не переноситься», ланц «ланцюг», линва «міцна мотузка або ланцюг, яким прив'язують рубель на возі», верета «1) домоткане С Л. І. Пена, 2013. 
вовняне або лляне рядно; 2) старе рядно», слойок «скляна банка, слоїк». Напр.: Над прірвою - сумні канатохідиі / щзоночі хилиткий долають шлях, хоч линви, по якій ідуть вони, не видно [5, с. 99] та ін.

Репрезентовані у творах І. Малковича субстантиви з абстрактним значенням, серед яких туск «туга, сум», гризота «клопіт, журба», тратуляиії «поздоровлення», нендза «нужда, злидні: Я хочу плакати, бо туск, / бо довгов'язий дощ і скелі, - / тебе втрачаю і не склею / нічого вже [4, с. 197]; Окрім того / перекажи букети гратуляцій [5, с. 21] та ін. Передають своєрідність гуцулів і номінації одягу, прикрас та матеріалів, 3 яких вони виготовляються: кошулька «сорочечка», тердан «жіноча прикраса для шиї», топірець «топірець (металевий або дерев'яний) 3 довгою ручкою, прикрашений орнаментом», позлітка «фольга». Напр.: Блакитні очі у царівен / $i$ золоті гердани [5, с. 54].

Гуцульський ономастикон маніфестований такими групами говірково маркованих найменувань: топоніми (Березів, Криворівня), гідроніми (Прут, Черемош), ороніми (Говерла, Чорногора, Карпати). Напр.: Я зірвусь проти Пруту й Дунаю [5, с. 35]; Там / де мені добре/ довкола гори - / невисокі переважно / $і$ я дуже тяжко / прийшов до розуміння / що невисокі вони тому - / бо ж ростуть углиб.../ Чорногори глибин [5, с. 121] та ін.

Високою частотою вживання в поезіях I. Малковича характеризуються назви свят християнського календаря, які тісно переплетені з язичницькими віруваннями гуцулів: Йвана, Івана Купала, Різдво, Меланка, Василя, Йордан. Найбільш використовуваними, як видно 3 наведених лексем, $€$ найменування празників зимоворіздвяного циклу. Напр.: На Йвана се було... Й хоч нині вже Василя, / та бачу як тепер: безсоння, супокій, / і напливає ніч [3, с. 59]; У ніч на Івана Купала / скарби палахкочуть в землі [3, с. 85]; Ми-мерщій від вікна - засуваємо двері і вікна - / i під стіл! - з-під стола на меланку дивитись найкраще $[4$, с. 210$]$ тощо.

Тісно переплетені у житті гуцулів два простори - реальний та ірреальний. На мовному рівні це виявляється у функціонуванні багатьох лексем на позначення надприродних сил та людей, які можуть, за народними віруваннями, керувати цими силами. У своїх віршах I. Малкович використовує низку демонімів: нечистий, копитатий, щезник, той, чугайстер, лісниця. Напр.: Як плела вінок ти вранці / сумно так, немов лісниця, / на сумні лякливі пальці / мружив око із чорниць я [4, с. 196]; А щуо просиш за ласкавість таку, / копитатий мій пане? [5, с. 107].

Зрідка вживаються у творах I. Малковича субстантиви інших 
лексико-семантичних груп, зокрема назви зброї (гвер «кріс, гвинтівка»), природних явищ (мла «імла»), тлум «натовп», мапа «географічна карта»: В тролейбусах, у тлумі, в миготінні / зітерлась икіра: ріже по живому / байдужсості пила, іржа цчинізму йліні [3, с. 17].

Порівняно невелику групу в аналізованих збірках складають прикметникові діалектизми. До них належать: ківна «тільна», моругий «про коня темно-сірої масті 3 плямами», наглий «1) невідкладний, спішний; 2) нахабний, грубий», чвалий «меткий, рухливий», зимний, студений «холодний». Напр.: В осінні вечори, у вечори студені, / непевне все якесь, як ворожбитський віск [4, с. 140]; У снах я боявся бика. / I ось він. / Моругої масті [5, с. 57].

Органічною складовою творів І. Малковича є гуцулізми-дієслова різної семантики, серед яких: банувати «тужити, сумувати, жалкувати за кимсь», вздріти «побачити», втворити «відчинити, відкрити», зфашкувати «спалахувати», корняти «будити», кутати «1) поратися коло домашнього господарства; 2) доглядати; поратися біля худоби», ладувати «вантажити», літувати «перебувати на полонині протягом літнього сезону», минатися «гинути, помирати», пантрувати «1) пильнувати, стежити; 2) доглядати», пастушuтu «пасти рогату худобу», перешпурити «перекинути», пуцувати «чистити», скугніти «1) скавуліти; 2) стогнати, скиглити», толочити «топтати», хапати «1) ловити; 2) брати; 3) збирати, громадити (про сіно)». Напр.: Якщуо добре придивиться - / можете уздріть / на сорочияі проти серия / черешеньки слід [4, с. 195]; тут / де ми тепер долітовуємо цуе літо / плакали колись ведмеді рудошерсті [5, с. 80]; Знову коні палають в степу, / гриви зфашкують раптом [5, с. 14]; Летии, як сто вітрів!.. Спиняйся / бо так всі гори потолочиш [3, с. 47]; Я любив тебе потайно, / так поспішливо і вмовкло - / так, мов квапляться отаву / захапати, щуоб не змокла [4, с. 196].

Репрезентовані в поетичних творах I. Малковича і прислівники 3 різними значеннями: видко «1) світло, ясно; 2) доступно зорові, видно», лепсько «погано», нагло «раптово», пусто «даремно», фурт «постійно, безперервно», маркотно «ніяково, моторошно», попасом «попаски, пасучись на ходу», сегорік «цього року», тогди «тоді». Напр.: Нехай молить пан кат, изоб лепськіше кипіло [3, с. 4]; Так пусто літо відійило вже й не дотягнешся рукою [4, с. 199]; Рядки у віршах, як порожні ясла: / сегорік не вродила конюшина [5, с. 134]; Дівчинко моя фіялковая, / чом ти мене не любии? - / чорний кінь прийде - свисне на мене - / тогди плакати будеш [5, с. 78] та ін. Трапляються у творах I. Малковича діалектні лексеми і серед службових слів, зокрема: най «хай, нехай», агій 
«виг. уживається для висловлення обурення, роздратування», ади «виг. уживається для висловлення здивування; диви, бач». Напр.: «Най би хоч баранчики / ніколи не виростали», - / отак гадав я собі під вечір / y Березові, / тримаючи в колінах / те перелякане диво [3, с. 49].

Для поезій I. Малковича характерним $є$ вживання діалектних лексем у переносному значенні, використання їх у складі порівнянь, що підсилює експресію поетичного мовлення: каштани иявіт згребли y тисячі копичок, щуо хилиталися $i$ пахли між листків [5, с. 65]; Сорочечка білесенька, / а личко, як без [5, с. 120]. Це свідчить про потужний образотвірний потенціал говірково маркованих слів, їх здатність бути засобами художнього змалювання дійсності.

В аналізованих поезіях через мову відображено деякі ментальні особливості гуцулів, зокрема звертання на «ви» до старших, у тому числі й до найрідніших людей - батька й матері, що виявляється у використанні особового займенника ви та відповідних дієслівних форм: Ой заваріме, мамцю, мені чай / із корінців сухого молочаю. / Ох, сині жслки на моӥх руках - / чого ж ви, мамщю, у такім одчаю? / Подайте мені в збанку молока / з листків блідо-зелених молочаю. / Усміхнене й просвітлене лице - / то, мамцю, все, шуо я вам залищаю... / А ви... ви не зривайте молочаю, / щуо завтра зранку дивно зацвіте... [5, с. 33] та ін.

Для творів І. Малковича властиве паралельне вживання в одному контексті діалектного й літературного слів: Ти також грав на тім баю, на тій забаві [4, с. 105]; Це спить квасоля - «кобили» [5, с. 105]. Автор часто використовує також прийом ампліфікації - своєрідне нанизування у порівняно невеликому текстовому просторі кількох діалектизмів, що сприяє точнішому змалюванню гуцульської дійсності, зануренню реципієнта в їі колорит: Це край, де мовкне спів флояр / під жсонови жертовний стукіт, / де так подібні до хлоп'ят / худі баранчики / $i$ буки [4, с. 205]; Лиш кахлі скалочку щуе видко, / де жновняр на коні: / при боці пістолєтко / $і$ горличка в вікні [5, с. 25] тощо.

I. Малкович вдається до своєрідного олітературнення деяких діалектних форм. Маємо на увазі передовсім нівелювання характерного для гуцульських говірок вживання голосного звука $i$ замість $a$ після м'яких приголосних: корняти замість корнєти, жовняр замість жовнір, князь - книзь, кнізь, княгиня - кнігині, книгині, копиця - копиці, пивницяя - пивниці тощо. Таке наближення гуцулізмів у плані вираження до загальновживаних лексем, звичайно, скорочує шлях до входження їх у скарбницю української літературної мови. Зазначимо також, що автор не обмежується використанням діалектних лексем у власних текстах, він уводить їх i в мовний 
простір перекладних творів. Напр.: твар, туск [4, с. 242].

Трапляються у збірках поодинокі авторські пояснення значень діалектних слів шляхом наведення загальномовного синоніма або ж стислого коментаря щодо вживання тої чи тої форми слова, відмінної від літературної: «В гуцульському діалекті замість грати кажуть йграти; замість частки но вживають ко: замість не бий-но - не бий-ко» [4, c. 105]. Це, на наш погляд, свідчить про свідоме вплетення діалектизмів у текстовий простір віршів задля ознайомлення читачів із говірково маркованими лексемами.

Свого часу автор актуального «Напучування» (Хай це можливо / $i$ не найсуттєвіме / але ти дитино / покликана захищати свойми долоньками / крихітну свічечку букви «ї» / а також / витягнувшись на пальчиках / оберігати місячний серпик / букви «є» / щэо зрізаний з неба / разом із ниточкою / бо кажуть дитино / щз мова наша - солов їна / гарно кажуть / але затям собі / щзо колись / можуть настати і такі часи / коли нашої мови / не буде пам'ятати / навіть найменший / соловейко / тому не можна покладатися / тільки на солов їв / дитино [4, с. 173]) зумів привернути увагу українців до неповторності рідної мови й необхідності зберігати їі недоторканною на всіх рівнях. Активно використовуючи різні пласти говірково маркованої лексики у своїх творах, талановитий митець робить іï доступнішою для широкого кола мовців і таким чином торує їй шлях із поступового забуття до залучення в фонд загальновживаних слів (принаймні певної частини).

Отже, територіальні діалектизми є невід'ємною ознакою ідіостилю І. Малковича. Їх використання в поетичних полотнах митця $\epsilon$, на наш погляд, цілком закономірним і зумовлене насамперед тим, що гуцулізми $є$ частиною його мовної свідомості. Вони сприймаються не як одиниці, що засмічують літературне мовлення, а як органічні елементи художнього світоопису. За допомогою діалектизмів авторові вдається передавати особливості світосприймання, світовідчуття та світобачення жителів Гуцульщини. Діалектні перлини надають різнобарвному запашному вінку літературної мови колоритного забарвлення, оригінальності.

\section{Література}

1. Грещук В. Південно-західні діалекти в українській художній мові. Нарис / В. Грещук, В. Грещук. - Івано-Франківськ : Вид-во Прикарпатського національного ун-ту імені Василя Стефаника, 2010. - 309 с.

2. Грещук В. В. Територіальні діалекти і мова художньої літератури : типологія зв'язків // Грещук В. В. Студії з українського мовознавства : Вибрані праці / Упор. Р. Бачкур. - Івано-Франківськ : Місто НВ, 2009. - 520 с. 
3. Малкович І. А. Вірші / І. А. Малкович. - К. : Укр. письменник, 1992. - 110 с.

4. Малкович I. Все поруч : Вибрані вірші, переклади, есеї, інтерв’ю / I. Малкович. К. : А-ба-ба-га-ла-ма-га, 2010. - 336 с.

5. Малкович I. Із янголом на плечі / I. Малкович. - К. : Поетична агенція «Княжів», 1997. - $150 \mathrm{c.}$

6. Малкович І. А. Ключ : Вірші / І. А. Малкович. - К. : Молодь, 1988. - 88 с.

7. Соло з квінтетом: Калейдоскопічне інтерв'ю, що його у різні роки записали Павло Вольвач, Ольга Унгурян, Олена Кириченко, Тетяна Терещенкова, Людмила Таран та ще дехто нез'ясований... // Малкович I. Все поруч : Вибрані вірші, переклади, есеї, інтерв'ю. - К. : А-ба-ба-га-ла-ма-га, 2010. - С. 302-327.

Стаття надійшла до редакції 15.10.2013 р. 